\title{
Modelling the Deformation of Steel-bars in Reinforced Concrete Beams Submerged in Lagoon
}

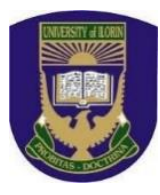

\author{
J. O. Akinyele ${ }^{1 *}$, U. T. Igba ${ }^{1}$, F. M. Alayaki ${ }^{1}$, S. I. Kuye ${ }^{2}$ \\ ${ }^{1}$ Department of Civil Engineering, Federal University of Agriculture, Abeokuta, Nigeria. \\ ${ }^{2}$ Department of Mechanical Engineering, Federal University of Agriculture, Abeokuta, Nigeria.
}

ABSTRACT: Corrosion of steel and spalling of concrete in reinforced concrete elements have become a common occurrence in structures that are built around marine environment. This research investigated the effect of chloride on the steel in reinforced concrete beams. Mechanical tests such as; compressive, flexural and bond strengths were done on replicate concrete elements which were cast and buried for a maximum of one year in the Lagos lagoon. Twentyfour number of $150 \mathrm{~mm}$ x $150 \mathrm{~mm} \times 600 \mathrm{~mm}$ sized reinforced concrete beams were cast for the flexural strength test, while forty-eight concrete cubes were cast for both compressive and bond strength tests, samples were cured in both lagoon and fresh water (The fresh water is for the control). A finite element program, ANSYS was used to model the deformation (deflection) of the steel reinforcement in the beams. Results showed a general reduction in compressive, flexural and bond strengths for the concrete samples buried in the lagoon, while those buried in freshwater showed an increase in strength as the concrete ages. The modelled results of the reinforcement showed a one-year deformation rate $(r=0.0181)$ in the steel of concrete buried in lagoon water. This value was used to estimate the future and past deformation values of these reinforcements due to chloride attack.

KEYWORDS: Chloride, lagoon water, steel, reinforced concrete, deformation

\section{INTRODUCTION}

Reinforced concrete elements have been in use in the construction industry for many decades, and this may continue for many years to come. However, one major problem that concrete has faced over time is deterioration, especially for reinforced concrete in marine or coastal environment.

Deterioration of reinforced concrete structures due to harsh environmental conditions has led to performance degradation of these elements. The premature deterioration of structures before completing expected service life is a major concern for engineers and researchers. Deterioration rate of structures depends on the exposure conditions and extent of maintenance (Sanjeev et al., 2014).

The most common causes of deterioration in steel reinforcement through corrosion is the ingress of chloride into reinforced concrete (Torres et al., 2004, Akinyele et al., 2018). Corrosion is the chemical or electrochemical reaction between a material, usually a metal and its humid or hydrated environment, which causes the material and its properties to deteriorate (Neville, 2012). Corrosion is a radical destructive process which takes place in a material, causing the material to deteriorate progressively with time (Suvash and Adewumi, 2018). The damage caused by corrosion to bridge, highway and other structural elements have brought about a huge

*Corresponding author: akinyelejo@ funaab.edu.ng economic loss to many countries of the world. In the USA, it is reported that 300-400 million dollars per year are required for the renovation of bridges and car parks alone ( $\mathrm{Li}$ et al., 2009). In the UK, $£ 500$ million is spent on concrete repair per year, while in China, the annual loss due to corrosion has reached 100 billion RMB (Li et al., 2009).

In reinforced concrete, corrosion of steel reinforcement is an electrochemical reaction, in which ions pass from one medium to another. The hydration process in concrete operate mainly in the alkaline medium $(\mathrm{pH}>7)$ and forms thin passive protection layers on the steel. This layer consists of a degree of hydrated iron oxide- $\mathrm{Fe}^{2+}$ and $\mathrm{Fe}^{3+}$, and it is a few nanometres thick. The layer is secured from any form of mechanical damage, but the ingress of chloride ions $\left(\mathrm{Cl}^{-}\right)$ through tiny pores in concrete will cause this layer to break after chemical reactions have taken place, then corrosion of the steel will then set in. The resistivity of concrete depends on the corresponding corrosion in concrete (Kumar 1998; Liu and Weyers 1998; Paul and Van Zijl 2017; Van Zijl and Paul 2018; Langford and Broomfield 1987; Bertolini et al 2004).

The following reactions occur at anode and cathode; Anode:

$\mathrm{Fe} \rightarrow \mathrm{Fe}^{2}++2 \mathrm{e}-\left(\right.$ Metallic iron), $\mathrm{FeO} .\left(\mathrm{H}_{2} \mathrm{O}\right) \mathrm{x}$ (Rust)

Cathode:

$1 / 2 \mathrm{O}_{2}+\mathrm{H}_{2} \mathrm{O}+2 \mathrm{e}-\rightarrow 2 \mathrm{OH}$. 
(Mehta and Monteiro 2006).

The presence of oxygen and humidity (water) are two essential parameters that normally start up corrosion process, the rate of corrosion will be slow if these two elements are absent (Isgor and Razaqpur 2006; Gaidis 2004; Mullick 2004).

The following reactions show how corrosion takes place;

$$
\begin{aligned}
& \mathrm{Fe}^{2++} 2 \mathrm{OH}^{-} \rightarrow \mathrm{Fe}(\mathrm{OH})_{2} \text { (Ferrous Hydroxide) } \\
& 4 \mathrm{Fe}(\mathrm{OH})_{2}+2 \mathrm{H}_{2} \mathrm{O}+\mathrm{O}_{2} \rightarrow 4 \mathrm{Fe}(\mathrm{OH})_{3} \text { (Ferric Hydroxide) } \\
& 2 \mathrm{Fe}(\mathrm{OH})_{3} \rightarrow 2 \mathrm{H}_{2} \quad \mathrm{O}+\mathrm{Fe}_{2} \mathrm{O}_{3} \cdot \mathrm{H}_{2} \mathrm{O} \quad \text { (Rust) }
\end{aligned}
$$

A lot of research has been done to overcome the problem of corrosion in reinforced concrete structures. Some corrosion inhibitors have been developed, and different protective techniques against corrosion have also been suggested. Xu et al. (2012), inferred that fly ash will increase the corrosion resistance of concrete by reducing concrete porosity, by this, the rate of penetration of harmful ions can be reduced. The use of super-plasticizers and mineral admixtures such as pozzolanic materials was suggested by Maslehuddin et al. (1992). The low-nickel stainless bar is known to reduce the rate of corrosion by providing high alkaline concrete pore solution (Criado et al., 2011). Steel corrosion can be reduced by the use of amino alcohol corrosion inhibitors (Jamil et al., 2005; Morris and Vazquez, 2002). Carbonation depth can be reduced with Calcium nitrate corrosion inhibitors by improving chloride threshold values (Sideris and Savva, 2005). Benzotriazole and polyvinylpyrrolidone also improve corrosion resistance (Ann et al., 2006; Gurten et al., 2005).

The degradation of the concrete elements and corrosion of the reinforcement of some bridge structures on the Lagos lagoon in Nigeria has called for the investigation of the deformation and structural integrity of this very important structures. Figures 1 and 2 showed the corroded reinforcement and steel sheeting of a bridge and a jetty on the Lagos lagoon. These structural impediments have been giving stakeholders in the construction industry serious concern and it has motivated this investigation. This work aims at determining the rate of deformation of steel bars in reinforced concrete elements buried in chloride infested water environment, using both physical and computer modelled reinforced concrete beams under sustained loading.

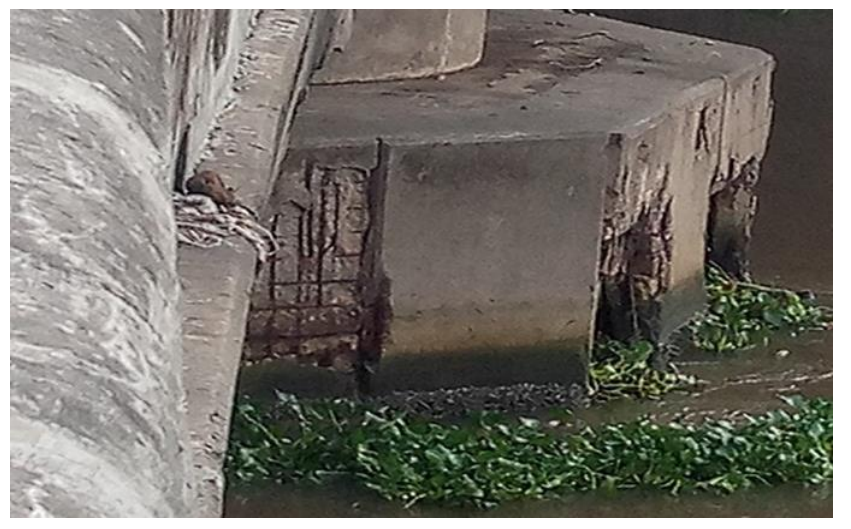

Figure 1: Corroded Reinforcement in Concrete.

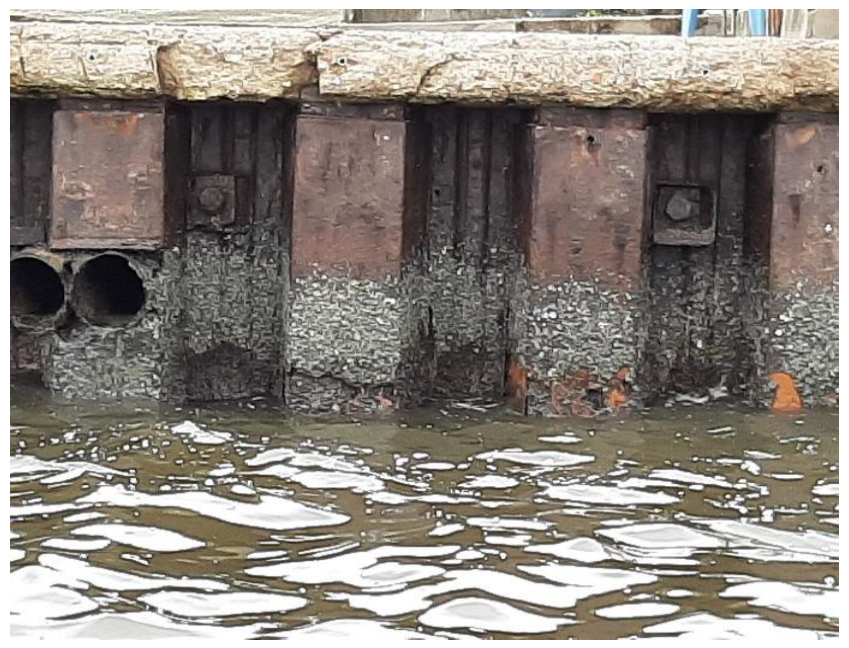

Figure 2: Corroded Sheet pile on the lagoon.

\section{MATERIALS AND METHODS}

\section{A. Chemical Analysis of Water Samples}

The $\mathrm{pH}$, salinity, turbidity and the composition of ions such as $\mathrm{Cl}^{-}, \mathrm{SO}_{4}{ }^{2-}, \mathrm{Fe}^{2+}$ in the water samples were analysed for both the fresh and lagoon water in accordance to BS 8550 (2010) at the University of Lagos Concrete Laboratory, Akoka, Lagos.

\section{B. Preparation of Concrete Samples}

The experimental analysis considered two sets of the specimen having three replicates of concrete beams, concrete cubes and concrete cubes for the pull-out test. In this experimental program, concrete specimens designated as $\mathrm{BL}_{40}$ were fully submerged in natural seawater that contains a high concentration of salts (chloride and sulphate) in the Lagos lagoon which is an offshoot of the Atlantic Ocean, at a depth of $3 \mathrm{~m}$ and close to the third mainland bridge. Other sets of concrete which served as the control and were designated as $\mathrm{BF}_{40}$, were cured in freshwater, at the civil engineering laboratory of the Federal University of Agriculture Abeokuta. The target strength of concrete in this experiment was 40 $\mathrm{N} / \mathrm{mm}^{2}$ with a water-cement ratio of 0.45 (concrete mix ratio 1:1:1). These are the average values used for the design of bridge structures in Nigeria based on available information BS 5400 (1990).

Batching were done by weight according to ASTM C31 (2011) and BS 1881-2 (2011). A total of forty-eight (48) cubes $(150 \times 150 \times 150 \mathrm{~mm}$ sized) were prepared for the compressive and bond strength test, while a total number of twenty-four (24) reinforced concrete beams of size $150 \mathrm{~mm} \mathrm{x}$ $150 \mathrm{~mm}$ x $600 \mathrm{~mm}$ were cast with $12 \mathrm{~mm}$ diameter high yield steel reinforcing bars according to ASTM D790 (2014) and BS EN 12390-3 (2009) for the flexural strength test.

The curing of the concrete samples (cubes, beams and cubes for pull out test) were carried out at 28, 90, 220 and 365 days. Samples cured in freshwater were cured in a curing tank in the laboratory at a temperature of $23 \pm 5{ }^{\circ} \mathrm{C}$ depending on the season of the year, while the other samples were cured in the Lagos lagoon. 


\section{Compressive Strength Test}

At the end of each curing regime, the crushing of the concrete cube was done in the concrete and soil mechanics laboratory with the use of Compression Testing Machine (the machine used was CN 370, $2000 \mathrm{kN}$. Impact test equipment). The crushing was done at the rate of $405 \mathrm{kN} / \mathrm{min}$ following BS 12390-3 (2009). The cubes were removed from the curing tank and lagoon water and wiped with a dry cloth. The cubes were tested to failure by crushing, the failure load was divided by the area of each cube to obtain the compressive strength of the samples. The average compressive strength for each specimen was taken from three replicates of each cube as the compressive strength.

\section{Flexural Strength Test}

This test was carried out on the beam specimens using a Universal Testing Machine (Okhart Digital Machine, OK 600 $\mathrm{kN}, 2012$ model). The beams were simply supported at the ends, with the load applied at the mid-span of each beam to form a three-point loading arrangement. At the end of the curing days, the beams were removed from both the lagoon and freshwater and taken to the laboratory for the testing. The load was gradually applied on each beam until failure of the beams, three replicates of each beam were tested and the average results were used. This test was done following the ASTM D790 (2014) standard.

\section{E. Bond Strength Test}

A $12 \mathrm{~mm}$ diameter high yield steel rod was cut into short pieces of $250 \mathrm{~mm}$ length and placed at the centre of the mould which was cleaned and oiled. The steel rod extended $50 \mathrm{~mm}$ outside the mould on both sides. The concrete was mixed to homogeneous state using a mobile rotating mixer, the fresh concrete was then placed in a mould in three layers using a hand trowel. Each layer was compacted using $16 \mathrm{~mm}$ diameter tampering rod and tamped 25 times. The specimens were then de-moulded after 24 hours of casting and some specimen were cured in freshwater while the remaining samples were buried in the lagoon water for curing.

At the end of each curing days (28, 90, 220, and 365 days), the samples were then subjected to the pull-out test. The testing machine for this pull-out test was a loaded rig on which a load cell equipment was mounted. The steel rod was held by the upper jaw of the machine while the concrete cube was supported by two steel elements. The force was applied at a loading rate of $5 \mathrm{kN}$ per seconds by the hydraulic jack by pulling out the steel rod from the concrete cube. This test was done by following ASTM C234 (1991) and BS EN 1542: (1999). The bond strength (bond stress) was calculated using the standard formula:

$B s=\frac{P}{l \pi \emptyset}$

Where $\mathrm{P}=$ failure load (ultimate load) $\mathrm{kN}$,

$l=$ embedded length $(150 \mathrm{~mm})$,

$\emptyset=$ Steel reinforcement bar diameter $(12 \mathrm{~mm})$.

Figures 3 and 4 showed the cubes used for the bond test at 28 and 365 days for samples buried in lagoon water, while Figures 5 and 6 showed the samples cured in freshwater at 28 and 365 days. The rust on the samples cured in lagoon water is very conspicuous when compared to the samples cured in freshwater.

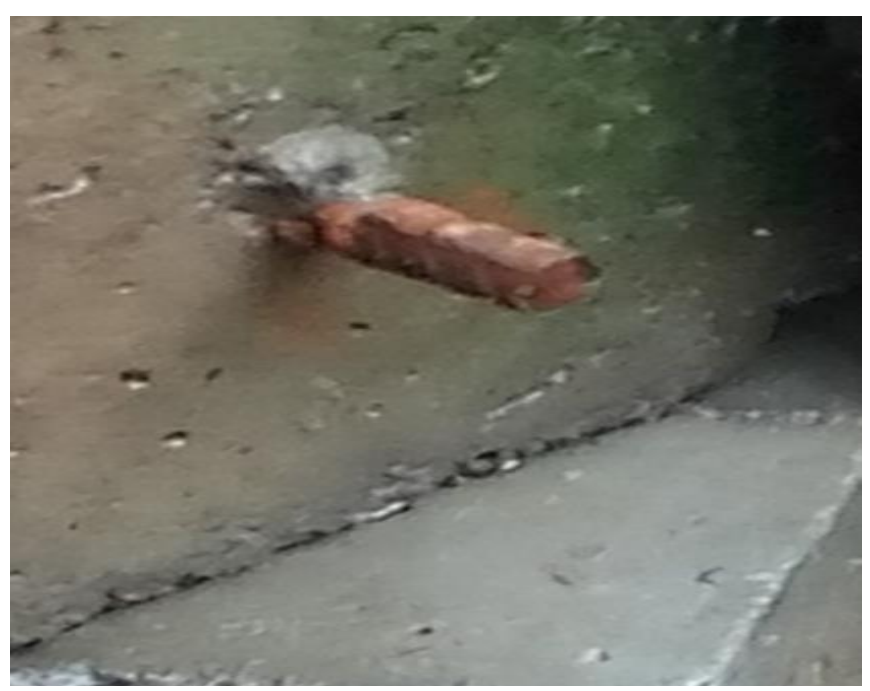

Figure 3: $\mathrm{BL}_{40}$ at 28 days curing.

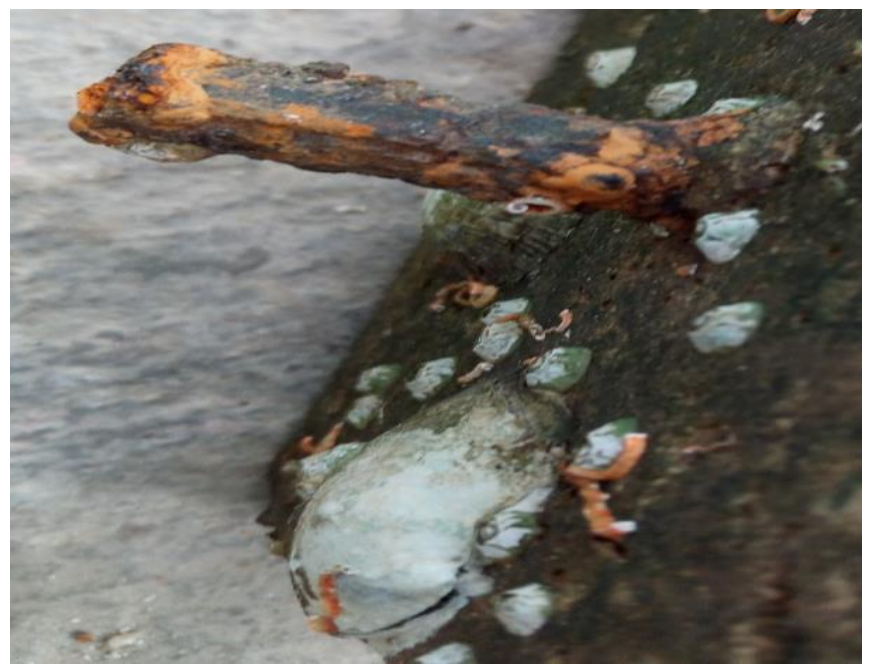

Figure 4: $\mathrm{BL}_{40}$ at 365 days curing.

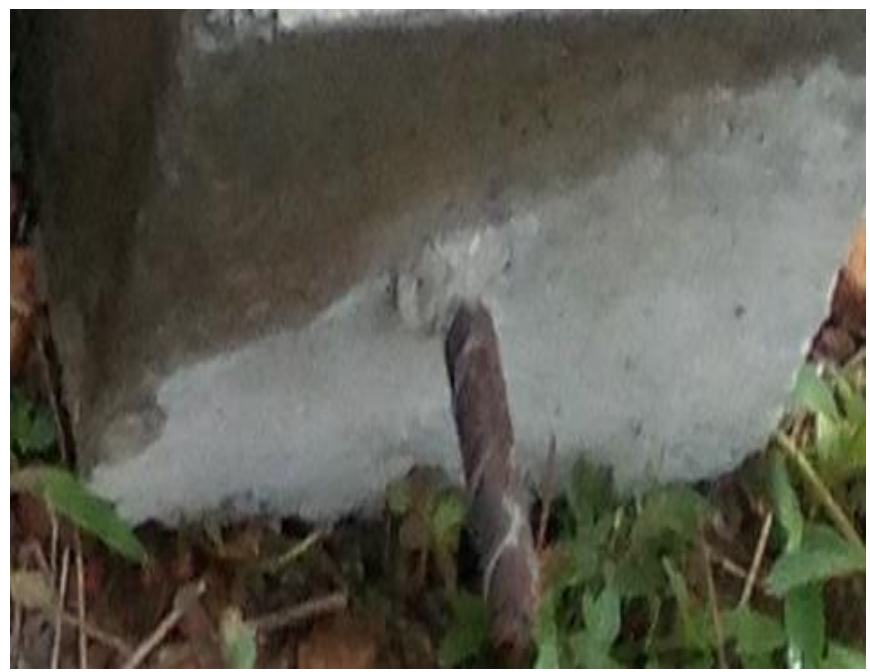

Figure 5: $\mathrm{BF}_{40}$ at 28 days curing. 


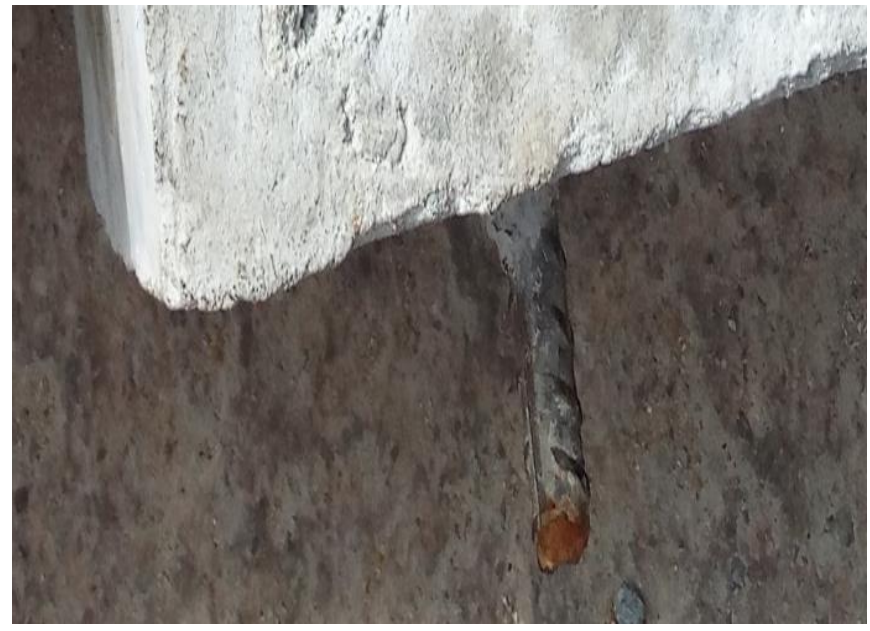

Figure 6: $\mathrm{BF}_{40}$ at 365 days curing.

\section{F. Scanning Electron Microscopy (SEM)}

The samples were cut into small sizes of $5 \mathrm{~mm}$ thickness and $15 \mathrm{~mm}$ length, after which the samples were coated with zinc coating, an electrically conductive material, which allowed the easy penetration of electron into the specimens. The samples were then mounted in the stem stub of the SEM machine, inside a relatively high pressured vacuum chamber, and electron gun was shot at the samples. Images from polished surfaces of these concrete fragments allow evidence of the microstructural arrangements of the concrete fragments. The test was carried out on concrete fragments at 28, 90, 220 and 365 days for the two samples. Scanning electron microscopy (SEM)-based images came from scanning electron microscopy JEOL JSM7600F.

\section{G. Finite Element Modelling}

Finite element modelling of the steel rod inside the concrete was carried out using the ANSYS software. The purpose of this analysis was to determine the effect of chloride ion on the steel and rebar deformation under sustained load at 28 and 365 days only. Flexural test results obtained from the laboratory were used for the beam loading, while the compressive strength obtained for $\mathrm{BL}_{40}$ and $\mathrm{BF}_{40}$ at the end of 28 and 365 days test were used for the modelling of the reinforced concrete beam strength. The characteristic strength of steel $\left(f_{y}\right)$ was $460 \mathrm{~N} / \mathrm{mm}^{2}$, the modulus of elasticity $\left(E_{s}\right)$ was $200 \mathrm{kN} / \mathrm{mm}^{2}$ and the factor of safety $\left(\gamma_{\mathrm{m}}\right)$ was 1.3 . These values were used to predict the rebar deformation in concrete (BS 8110-1, 1997). The formula adopted in the prediction of the deformation of steel rod for past and future years was:

$$
A_{f}=P_{c}[1 \pm r]^{\wedge} n
$$

where:

$\mathrm{A}_{f}=$ future year or past year value

$\mathrm{P}_{\mathrm{c}}=$ Initial value at 28 days

$r=$ One-year deformation rate

$\mathrm{n}=$ number of forecast years after base year $(\mathrm{n}>1)$

\section{A. Water Analysis Results}

\section{RESULTS AND DISCUSSION}

The results for the water analysis is shown in Table 1; the $\mathrm{pH}$ value for the lagoon water was 6.9 , which is within the neutral axis, the colour of the lagoon water was cloudy yellow, while that of freshwater was colourless, the freshwater was odourless while the lagoon water had an unpleasant sharp smell. The chloride in fresh water was very low and cannot significantly cause corrosion in steel when compared to lagoon water. It should be noted that the water samples were tested at the end of the curing days. The table showed that there is a very high concentration of chloride in the lagoon water, and the ion is known to attack iron rod in reinforced concrete structures. This must have been responsible for the deterioration observed in Figures. 1 and 2 above.

\section{B. Compressive Strength Results}

The compressive strength of the two specimens clearly showed that there was a gradual reduction in strength for $\mathrm{BL}_{40}$ and an increment in strength for $\mathrm{BF}_{40}$ throughout the curing period. The rate of increment in strength between 28 to 365 days in $\mathrm{BF}_{40}$ was $1.83 \%$, while $\mathrm{BL}_{40}$ experienced a reduction in strength by $7.69 \%$ during the same period. The optimum values for 28, 90, 220 and 365 days was attained in $\mathrm{BF}_{40}$. Compressive strength of concrete was highly affected by the sulphate attack in sample $\mathrm{BL}_{40}$. This result is a confirmation of the concrete spalling shown in Figures 1 and 2, of some of the bridge elements on the same Lagos lagoon.

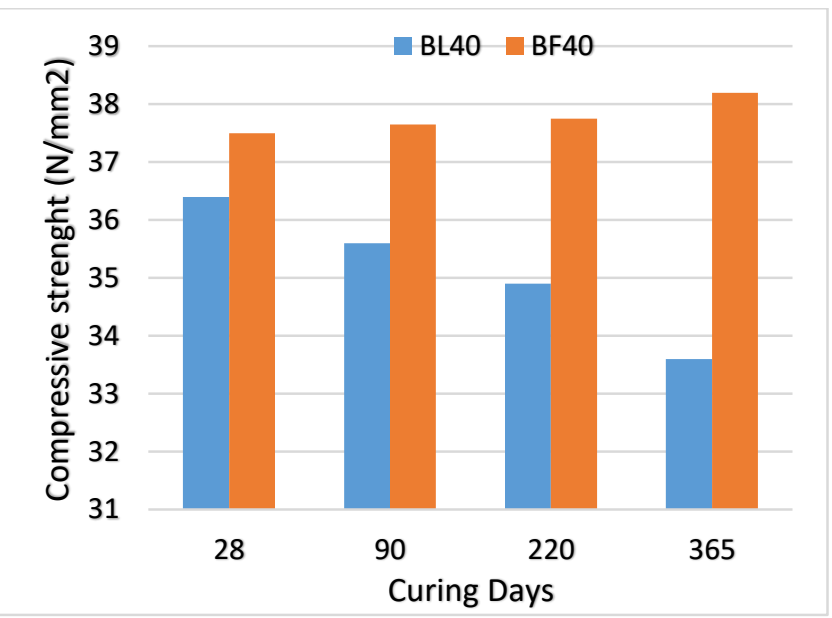

Figure. 7: Compressive strength of cubes.

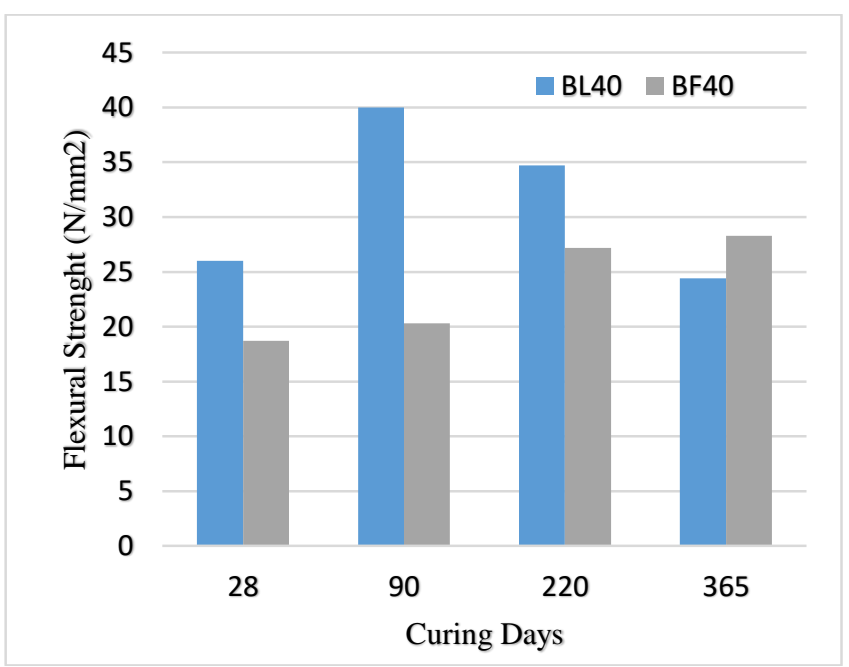

Figure 8: Flexural strength of beams. 
Table 1: Water analysis result.

\begin{tabular}{|c|c|c|c|c|c|c|c|c|c|c|}
\hline Water type & $\begin{array}{l}\text { Salinity } \\
\text { (mg/l) }\end{array}$ & $\begin{array}{l}\text { TDS } \\
\text { (ppm) }\end{array}$ & $\begin{array}{l}\text { Sediments } \\
(\mathrm{mg} / \mathrm{l})\end{array}$ & $\begin{array}{l}\mathbf{P H} \\
\end{array}$ & $\begin{array}{l}\mathrm{NO}_{3}^{-} \\
(\mathrm{mg} / \mathrm{l})\end{array}$ & $\begin{array}{l}\mathrm{ZnO} \\
(\mathrm{mg} / \mathrm{l})\end{array}$ & $\begin{array}{l}\mathrm{PO}_{4}{ }^{3-} \\
(\mathrm{mg} / \mathrm{l})\end{array}$ & $\begin{array}{l}\mathrm{SO}_{4}{ }^{2-} \\
(\mathrm{mg} / \mathrm{l})\end{array}$ & $\begin{array}{l}\mathrm{Cl}^{-} \\
(\mathrm{mg} / \mathrm{l})\end{array}$ & $\begin{array}{l}\mathrm{Fe}^{+2} \\
(\mathrm{mg} / \mathrm{l})\end{array}$ \\
\hline Lagoon & 469.7 & 650 & 18 & 6.9 & 7.28 & 7.36 & 0.02 & 20 & 260 & 0.42 \\
\hline Fresh & 28.9 & 190 & - & 6.9 & 2.32 & 2.4 & 0.01 & 6 & 16 & 0.06 \\
\hline
\end{tabular}

\section{Flexural Strength Test}

The flexural strength of $\mathrm{BL}_{40}$ in the first 90 days had the optimum average flexural strength in all curing environments. This was due to the chemical reaction between the lagoon water and the Ettringite, $\mathrm{Ca}(\mathrm{OH})_{2}$, and $\mathrm{C}-\mathrm{S}-\mathrm{H}$ gel which was actively generated from an early age of the beam structures which included the steel rod buried in the lagoon. However, this reaction took a reversal after the $90^{\text {th }}$ day with a gradual reduction in strength. At this stage, the negative effect of sulphate salts on the concretes and chloride on the steel reinforcement caused the reduction in strength. The freshwater cured beams gradually increased in strength from the 28 to the 365 days, leading to the optimum strength after curing for one year in $\mathrm{BF}_{40}$ with a flexural strength of 28.3 $\mathrm{N} / \mathrm{mm}^{2}$ compared to $\mathrm{BL}_{40}$ with flexural strength value of 24.4 $\mathrm{N} / \mathrm{mm}^{2}$ during the same period. Fig. 8 showed the result of the flexural test carried out on the beams.

\section{Bond Strength of Concrete Specimens}

The pull-out test results for the determination of bond strength in reinforced concrete structures is shown in Fig. 9, while the slipping distance of steel rod from concrete is shown in Fig.10. The bond strength results generally showed that $\mathrm{BF}_{40}$ had increased bond strength at the rate of $46.3 \%$ between 28 to 365 days with the peak strength at $18.60 \mathrm{~N} / \mathrm{mm}^{2}$. The $\mathrm{BL}_{40}$ sample, however, behaved differently, the bond strength peaked at 90 days with a value of $26.52 \mathrm{~N} / \mathrm{mm}^{2}$ but took a downturn to $16.79 \mathrm{~N} / \mathrm{mm}^{2}$ at the end of 365 days. The bond strength results of the sample cured in lagoon water $\left(\mathrm{BL}_{40}\right)$ is in agreement with the findings of Demis et al., (2010), Apostolopoulos (2012), Igba et al., (2019). Wherein both cases the bond strength increased with increase in corrosion level at the initial stage of curing and later decreased as the concrete ages. The initial increase in bond strength was due to the increased roughness of the steel-concrete interface caused by the growth of the expansive rust. The reduction in bond strength over a long period can be attributed to the reduction in cross-sectional area of steel and the loss of adhesive properties of the steel surface due to rust.

The reverse in bond strength can be linked to the negative effect of chloride that ingresses into the concrete and attacks the steel reinforcement, whereby allowing corrosion to set in and encouraged the eventual reduction in the bond strength and increased slipping distance between concrete and steel. The slipping distance of both concrete specimens increases as the curing days increased, but the samples buried in the lagoon generally had higher slip than the sample in freshwater, the optimum slip was observed on the $365^{\text {th }}$ day for both $\mathrm{BF}_{40}$ and $\mathrm{BL}_{40}$ at $11.5 \mathrm{~mm}$ and $14.5 \mathrm{~mm}$ respectively.
The general increment in bond strength of $\mathrm{BF}_{40}$ overtime further confirmed the report of Falade and Oyekan (2006) "that the bond strength of reinforced concrete structural elements depended on the bond between concrete and reinforcement to ensure effective transfer of stress from steel reinforcement to the surrounding concrete and that the bond was usually high at later age because the compressive strength of concrete and the grip effect on reinforcement increased with age". This however did not apply to the sample buried in the lagoon, due to chloride attack on the steel reinforcement, as showed in Figure 4.

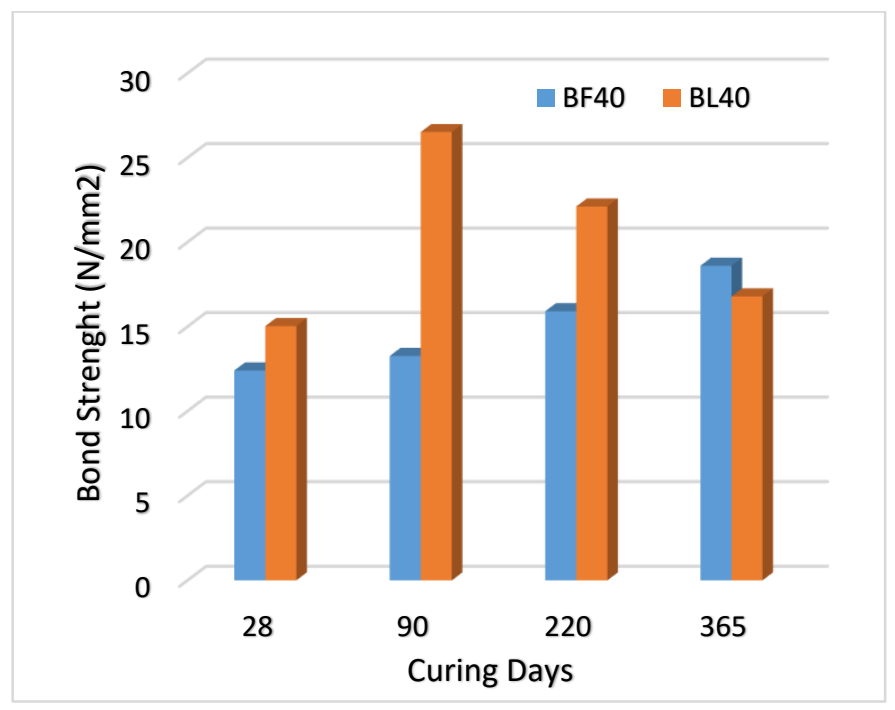

Figure 9: The bond strength result.

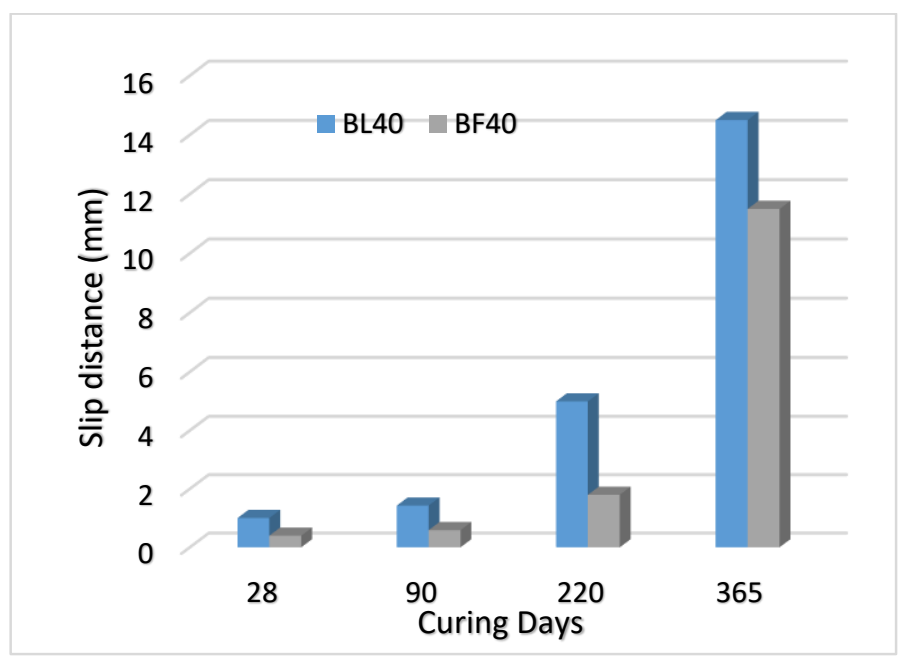

Figure 10. Slipped distance of steel rod. 


\section{E. SEM Analysis Results}

The purpose of this test is to determine the microstructural properties of each concrete samples at the end of the curing days. The SEM analysis results revealed the microstructural properties of each sample at 28, 90, 220 and 365 days. There were many portions of small hydration crystals and large holes in $\mathrm{BL}_{40}$ samples as seen in Figs. 11-17. The main reason was due to the small number of hydration crystals and their uneven distribution in the cement matrix, resulting in the production of many large pores and a decrease in the strength when compared to samples buried in freshwater.

The $\mathrm{BF}_{40}$ samples showed the microstructures of the uncorroded concrete samples, there were lots of fibrous and flocculent hydrated calcium silicate, but no obvious corrosion products or micro-damage was observed in the figures as no external sulphate ions entered into the concrete.

There were smaller holes in $\mathrm{BF}_{40}$ concrete samples as seen in the figures, which must have led to a general increase in strength (compressive, flexural and bond). The main microstructure features identifiable from their typical morphology were as follows: ettringite needles, calcium silicate hydrates (C-S-H), and tricalcium aluminate monosulphate hydrates (AFm) mainly seen in $\mathrm{BL}_{40}$.

Activities of Ettringite, $\mathrm{Ca}(\mathrm{OH})_{2}$, and $\mathrm{C}-\mathrm{S}-\mathrm{H}$ gel were actively generated in the early age of $\mathrm{BL}_{40}$ and the amounts of these materials generated were confirmed to increase with time. It was believed that the full submergence of these samples buried in the lagoon water ended up creating microstructures with more defects, as lots of more pronounced micropores were noticed in $\mathrm{BL}_{40}$ on the $365^{\text {th }}$-day sample.

In $\mathrm{BF}_{40}$ at 220 days, (Fig.16) the microstructure indicated that the cement hydration reaction was nearly complete and produced many needle-like and sheet-like crystals. The microstructure of $\mathrm{BF}_{40}$ was composed of reticular amorphous and needle-like $\mathrm{C}-\mathrm{S}-\mathrm{H}$ phase where calcium hydroxide crystals were locally embedded. The $\mathrm{BF}_{40}$ had a microstructure with fewer defects which in turn increased the generation of components such as hydrated calcium silicates (C-S-H) crystals, elements that improved the composite mechanical properties.

The ability of sulphate ion to penetrate the large pores of $\mathrm{BL}_{40}$ also encouraged the ingress of chloride ions present in the lagoon water into the concrete samples. The steel rod in the reinforced concrete beams was attacked by the chloride ion as the age of curing increased. This reaction must have led to the poor performance of $\mathrm{BL}_{40}$ in both the flexural and bond strength tests, and the generally large slip distance observed during the bond strength test (Fig.10). The corroded surface of the steel rod as a result of chloride attack reduced the bonding strength between the concrete and the steel reinforcements.

\section{F. Modelling of Steel Deformation in Flexure}

The flexural behaviour of the steel reinforcement in the concrete beams was modelled using ANSYS software for 28 and 365 days only. This was to mathematically predict the deformations of concrete beams and the steel bars inside the concrete under loading, taken into consideration the curing environment of each beam and the effect of chloride on the flexural resistance of the steel bar in concrete. The results from Figs. $18-25$ showed a very interesting trend, these results are summarised in Table 2.

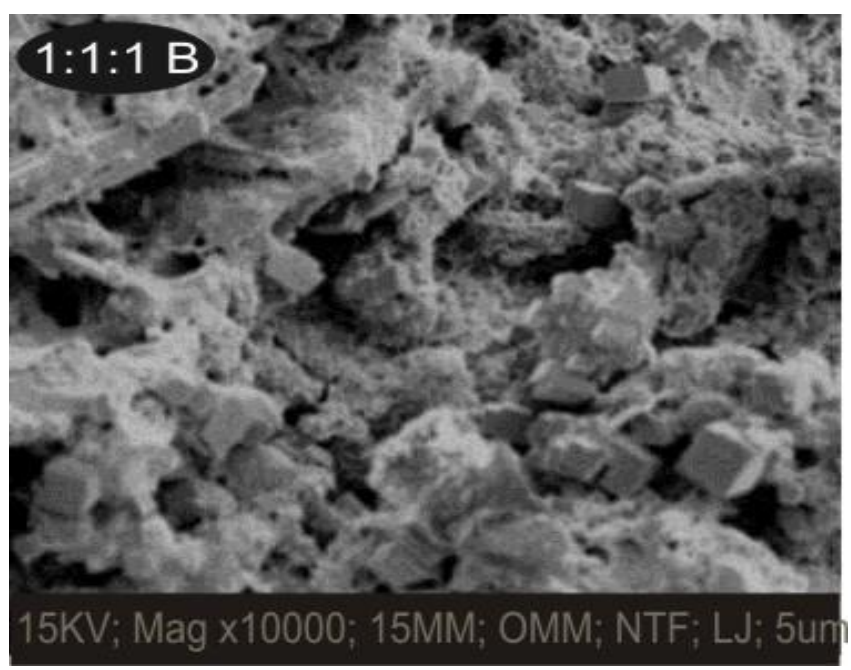

Figure 11. SEM Images of $\mathrm{BL}_{40}$ at 28 days.

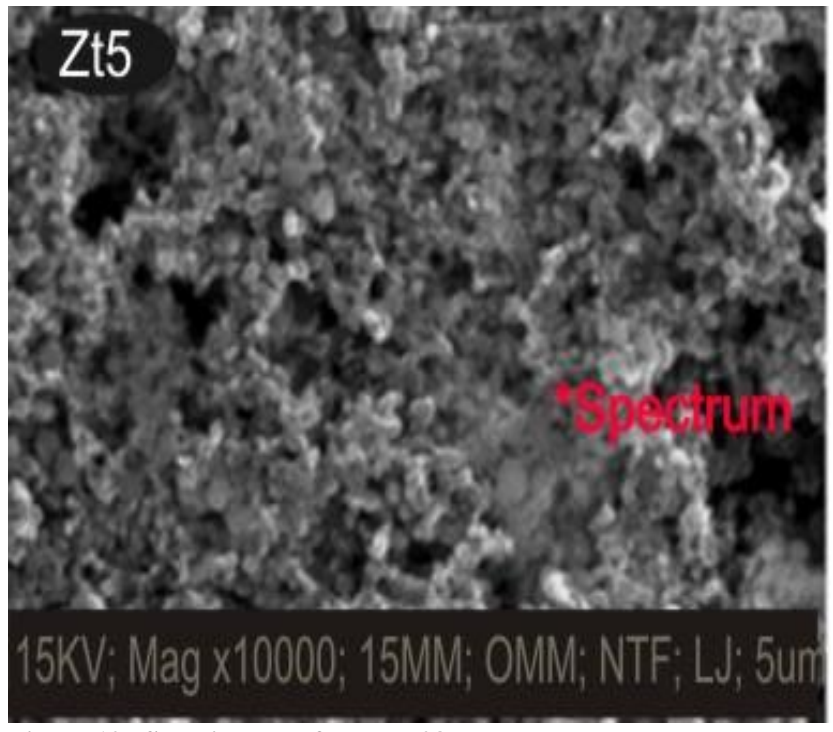

Figure 12. SEM images of $\mathrm{BF}_{40}$ at 28 days.

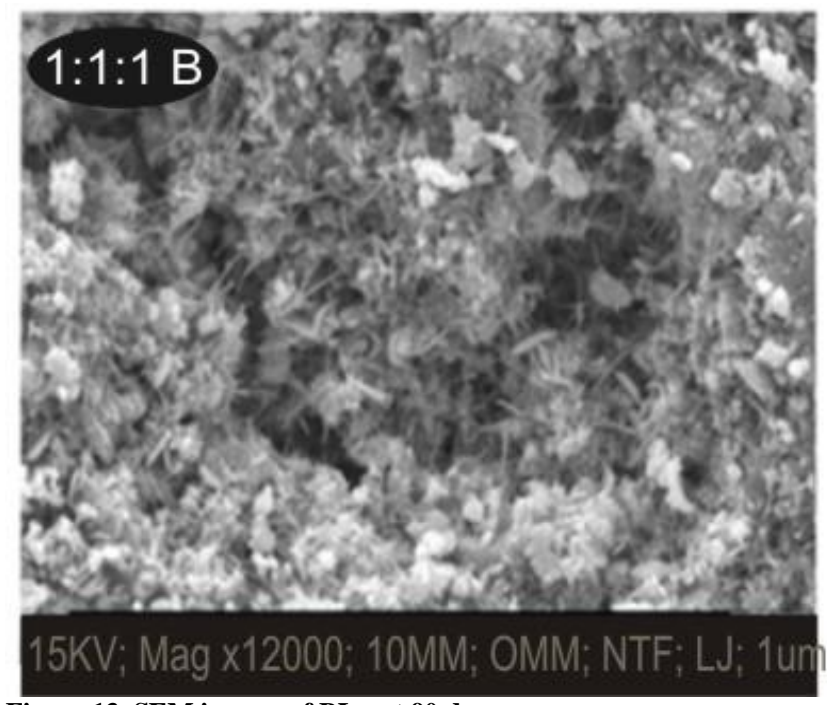

Figure 13. SEM images of $\mathrm{BL}_{40}$ at 90 days. 


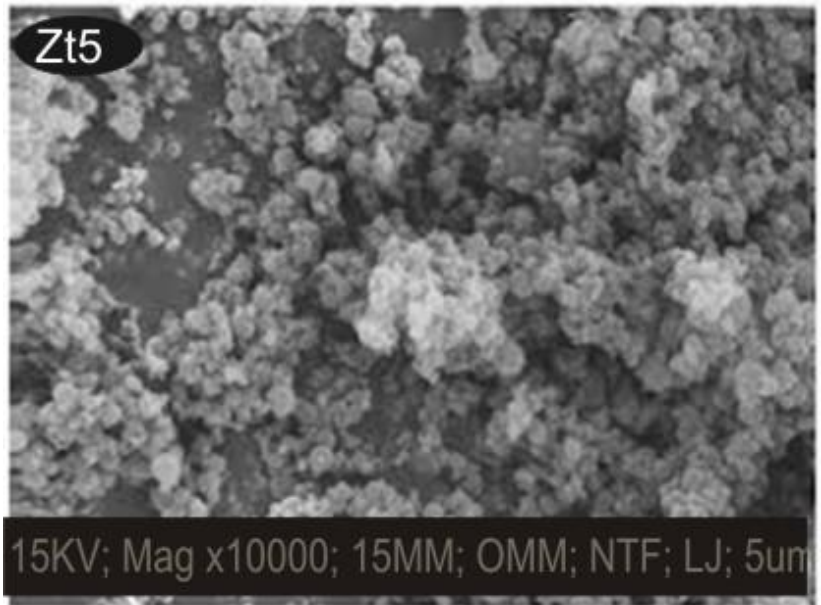

Figure 14: SEM images of $\mathrm{BF}_{40}$ at 90 days.

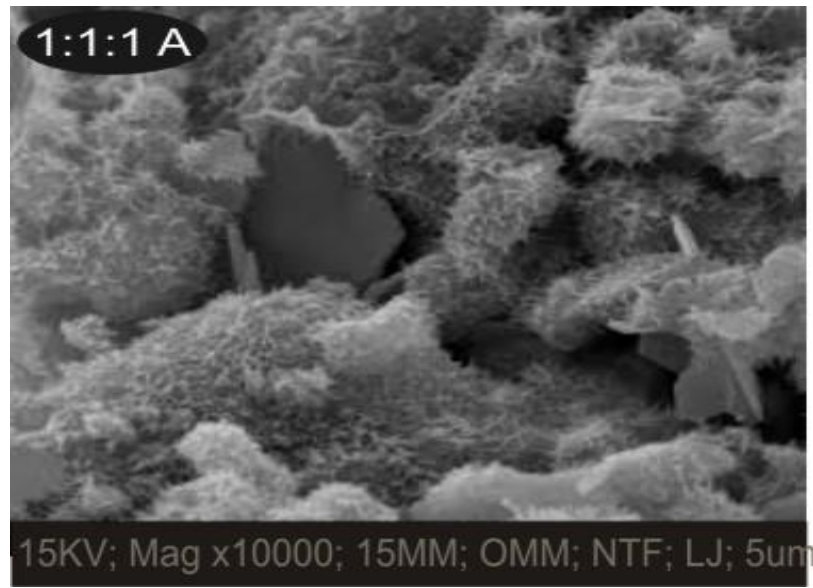

Figure 15. SEM images, of $\mathrm{BL}_{40}$ at 220 days.

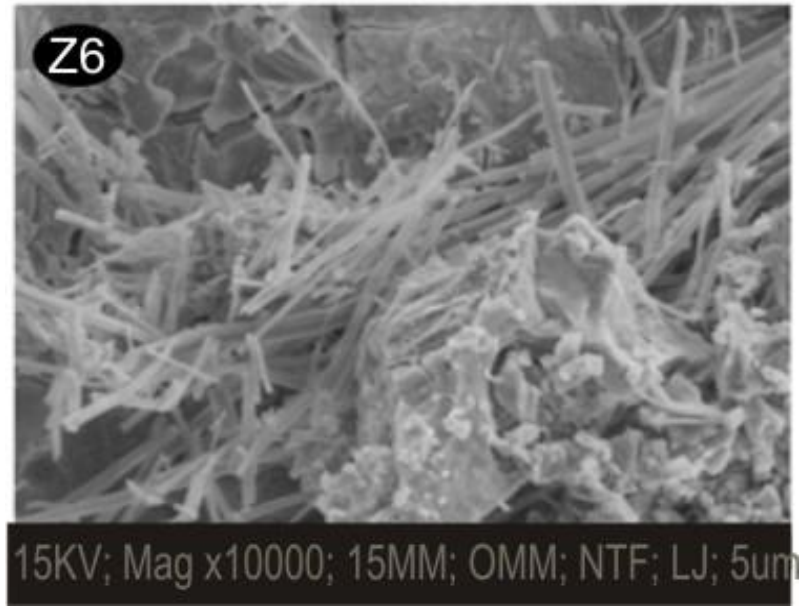

Figure 16: SEM images of $\mathrm{BF}_{40}$ at 220 days.

Table 2: Deformation of rebar and beams.

\begin{tabular}{lllll} 
Specimens & $\begin{array}{l}\text { Rebar } \\
\text { deformation }(\mathbf{m m})\end{array}$ & $\begin{array}{l}\text { Beam } \\
\text { deformation } \\
(\mathbf{m m})\end{array}$ \\
\hline & 28 & 365 & 28 & 365 \\
& days & days & days & days \\
$\mathrm{BF}_{40}$ & 3.75 & 3.72 & 3.94 & 3.91 \\
$\mathrm{BL}_{40}$ & 3.78 & 3.85 & 3.99 & 4.22 \\
\hline
\end{tabular}

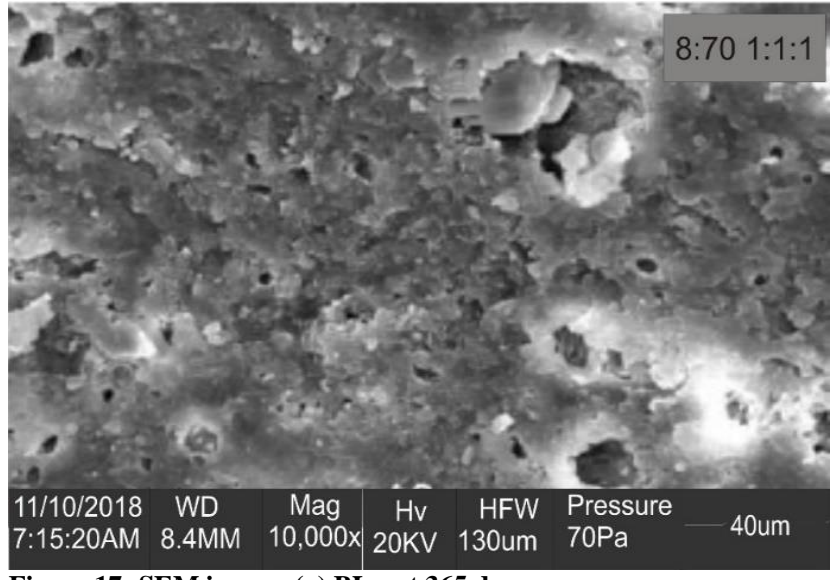

Figure 17: SEM images (g) $\mathrm{BL}_{40}$ at 365 days.

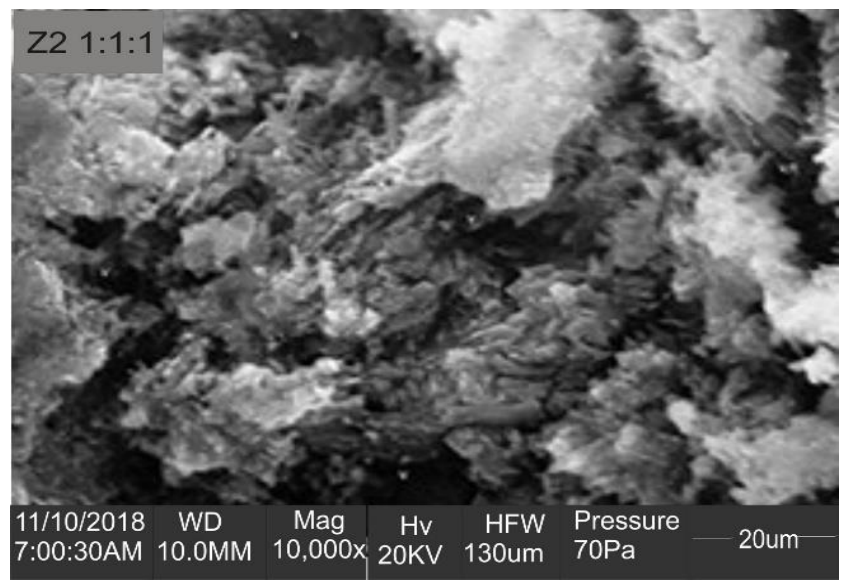

Figures 15: $\mathrm{SEM}$ images of $\mathrm{BF}_{40}$ at 365 days.

The results showed that the deformation of $\mathrm{BF}_{40}$ samples for both days was generally lower than $\mathrm{BL}_{40}$. Also, the values decreased as the curing age for $\mathrm{BF}_{40}$ increased while that of the $\mathrm{BL}_{40}$ samples increased as the curing age increases. This observation can be linked to the effect of sulphate attack on concrete and chloride attack on the rebar in the samples buried in the lagoon water. The weak concrete flexural and bonding strengths allowed more tensile stresses to act on the reinforcements, which allowed the large deflections experienced in the steel rod of the samples buried in the lagoon water. The deformation in the steel samples buried in freshwater was low and keep on reducing as the age increases because of the increased in concrete strength of this sample since there was a very small amount of chloride and sulphate ions that would have acted as impurities and attack the reinforced concrete beams.

The one-year deformation rate of steel rod in beams buried in the chloride infested lagoon is estimated to be $(\mathrm{r}=$ 0.0181 or $1.81 \%$ ). Based on equation 5 , the past and future deformation values can be obtained. The estimate for the deformation of the steel in ten years from the present will be $4.52 \mathrm{~mm}$, while the value in ten years ago is estimated to be $3.15 \mathrm{~mm}$. Most of the concrete structures on the Lagos lagoon have an average age of 40 years, going by the current values, the deformation of the rebar in forty years ago can be 
estimated to be $1.82 \mathrm{~mm}$, and these estimates are based on the annual deformation rate and the use of Eq. (5).

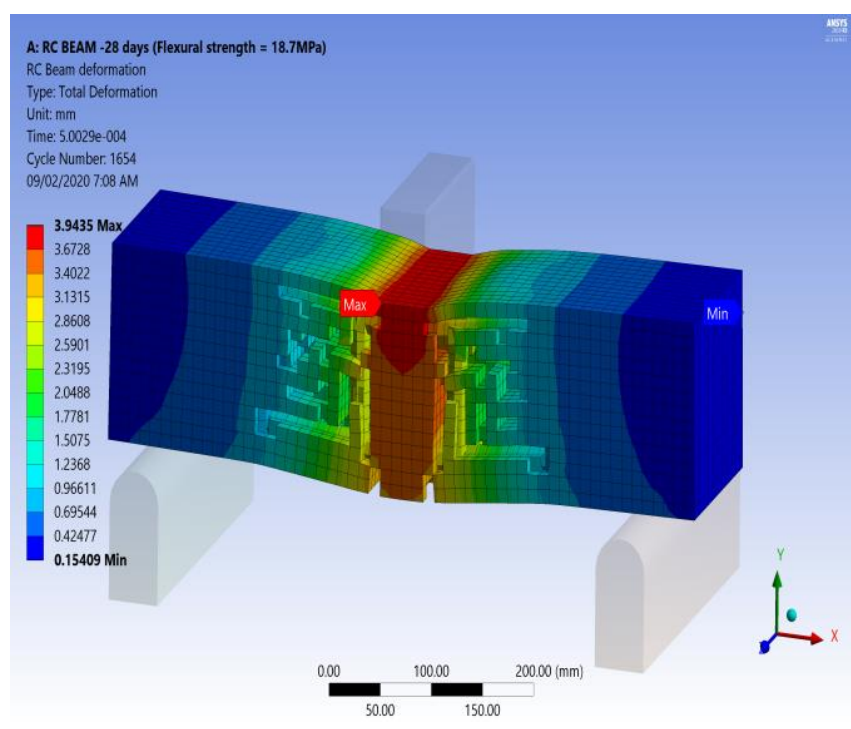

Figure 18: $\mathrm{BF}_{40} 28$ days beam deformation.

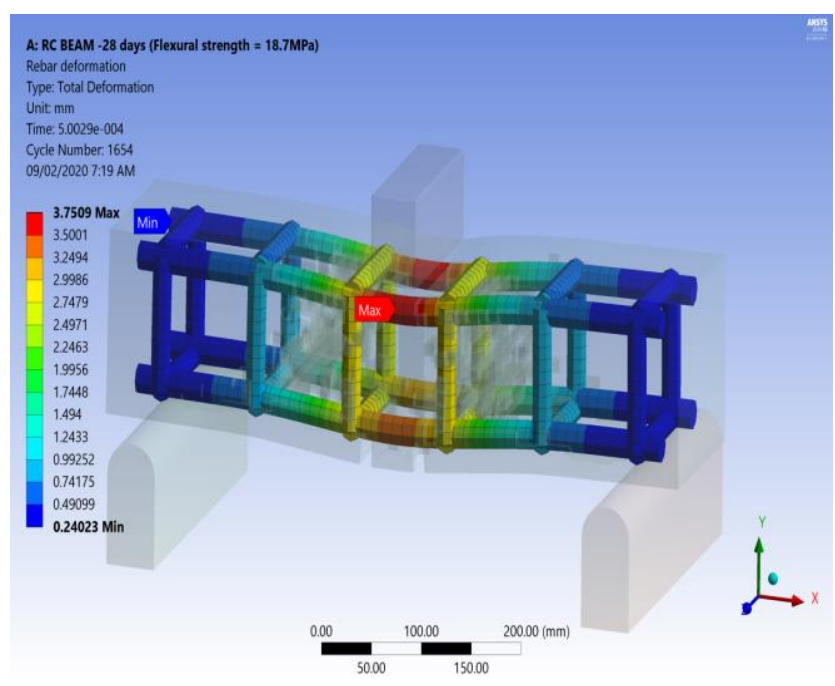

Figure19: $\mathrm{BF}_{40} 28$ days rebar deformation.

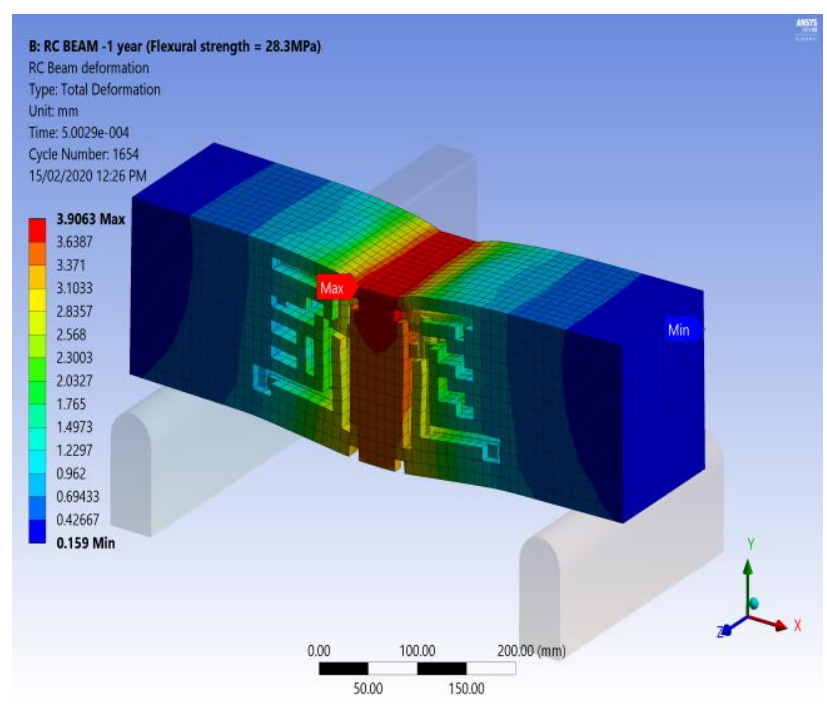

Figure 20: $\mathrm{BF}_{40} 365$ days beam deformation.

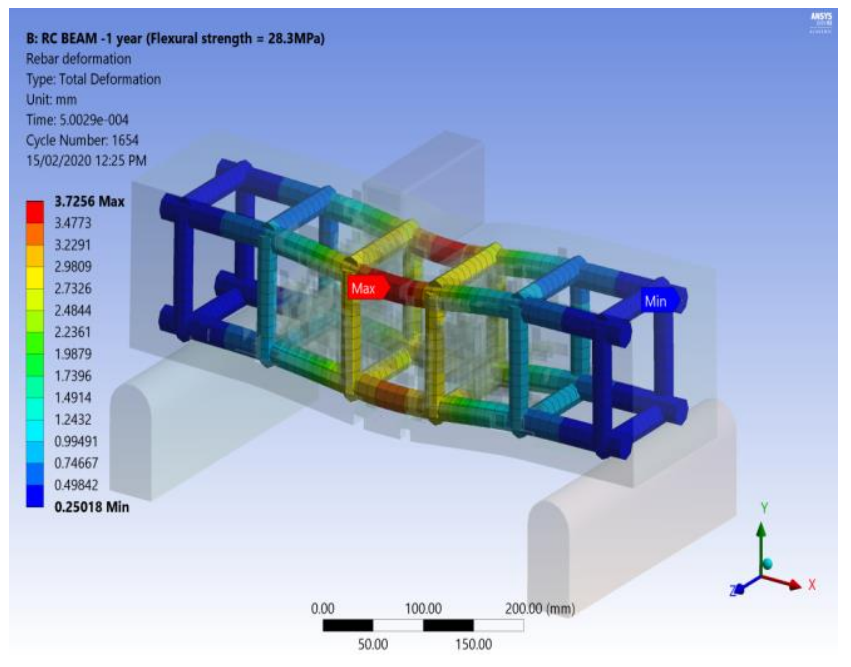

Figure 21: $\mathrm{BF}_{40} 365$ days rebar deformation.

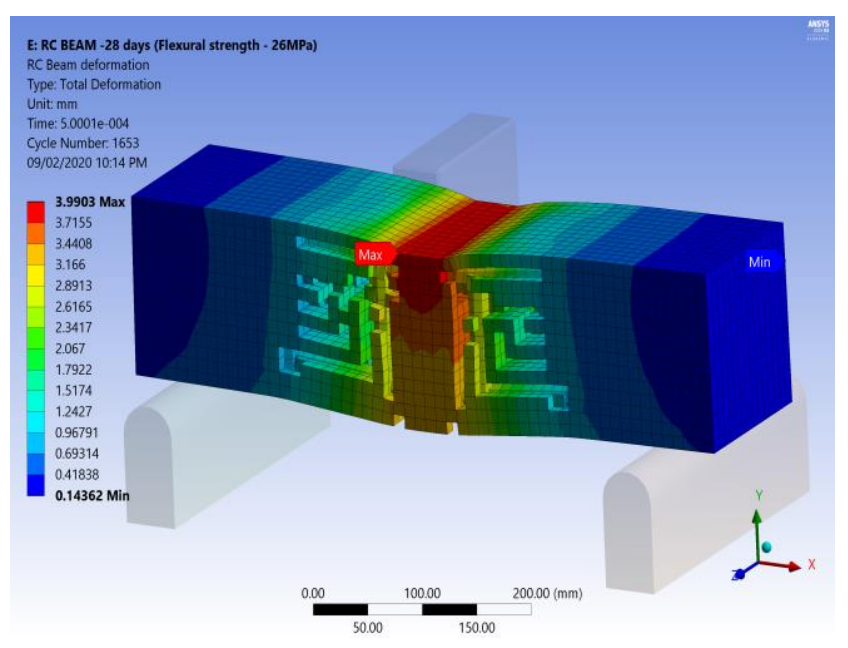

Figure 22: $\mathrm{BL}_{40} 28$ days beam deformation.

\section{CONCLUSION}

This experiment has investigated the role played by both sulphate and chloride ions on the deterioration of the structural members of some concrete elements buried in lagoon water and using fresh water as control.

The mechanical test on the concrete samples buried in the chloride infested lagoon showed depletion in strength as the concrete ages, while the samples in freshwater behaved like a typical concrete in a normal environment. The microstructural analysis revealed the large pores that were formed in the samples buried in the lagoon, these pores were formed as a result of chemical reactions between the concrete elements and sulphates ions, which created a weak bond within the concrete matrix, the large pores allowed the ingress of chloride ion into the concrete, and eventually exposed the reinforcement to attacks.

The corrosion in the steel as a result of chloride attack led to low bond strength and high slipping distance in the concrete buried in the lagoon. The modelling results revealed the effect of chloride on the high deformation and deflections that occurred in steel rods of concrete samples buried in the 
lagoon water when compared to the samples cured in freshwater. The modelling results were used to predict rebar deformation for future and past years. The deformation rate of steel bars in concrete buried in the chloride infested lagoon water within a year was estimated to be $0.0181(1.81 \%)$.

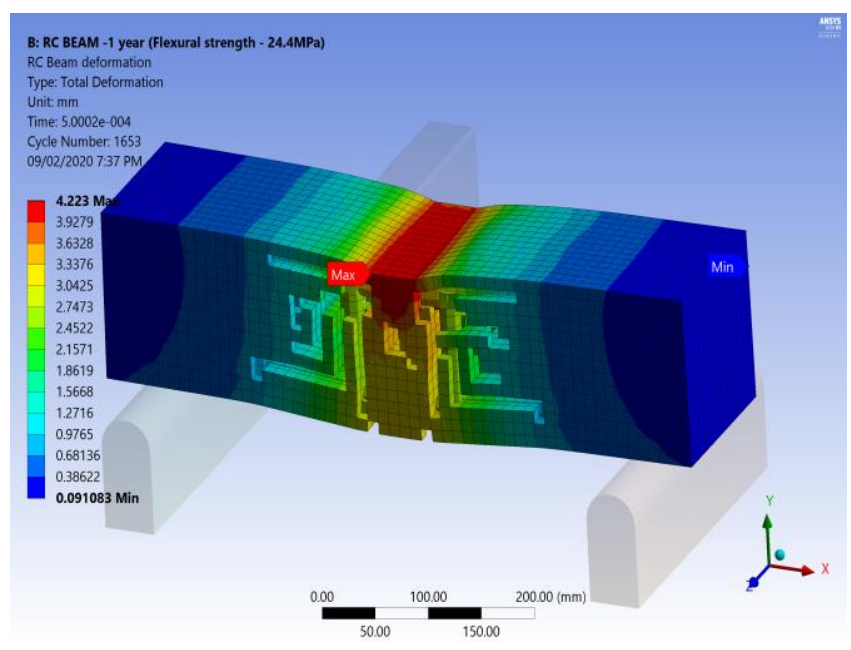

Figure 23: $\mathrm{BL}_{40} 28$ days beam and rebar deformation.

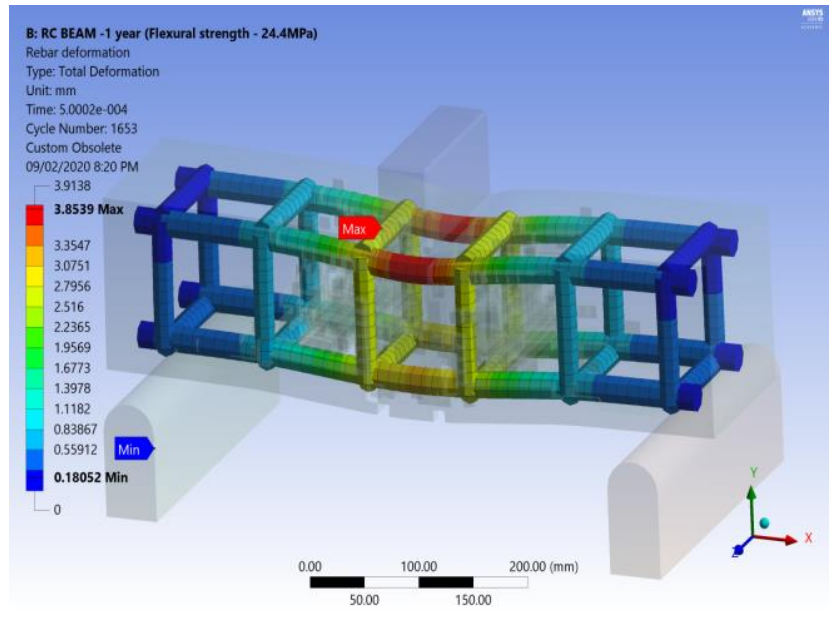

Figure 24: $\mathrm{BL}_{40} 365$ days beam deformation.

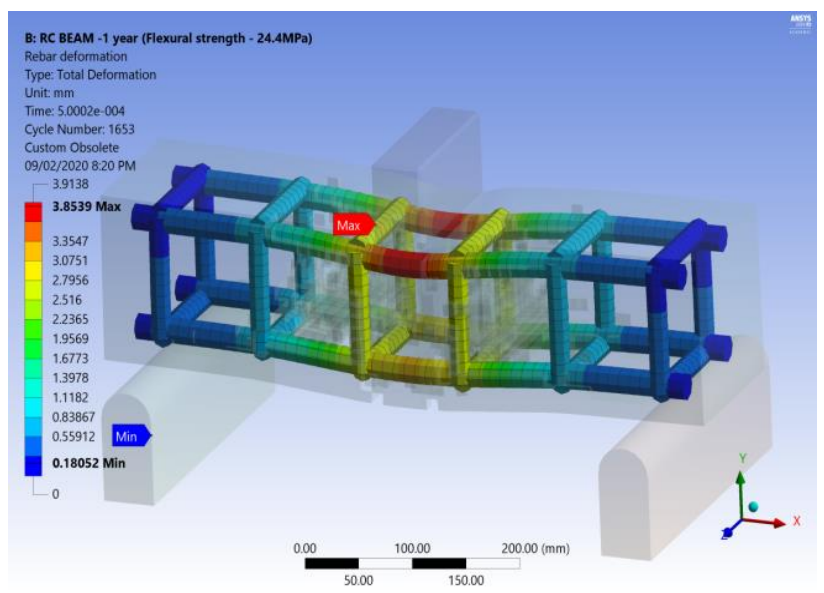

Figure 25: $\mathrm{BL}_{40} 365$ days rebar deformation.

\section{REFERENCES}

Akinyele, J.O.; P.A. Adewuyi; M.A. Idowu; P.N. Iroaganachi. (2018). The Effects of Varying Water-Cement Ratio on the Degradation of Concrete by Sulphate Salts. Fuoye Journal of Engineering and Technology, 3 (1): 152156.

Ann, K.Y.; H.S. Jung; H.S. Kim; S.S. Kim and H.Y Moon. (2006). Effect of calcium nitrite-based corrosion inhibitor in preventing corrosion of embedded steel in concrete, Cement and Concrete Research, 36 (3): 530-535.

Apostolopoulos, C. (2012). The consequence of chlorideinduced corrosion on steel bar and reinforced concrete structures. Journal of Applied Mechanical Engineering, 1(3): $1-2$.

ASTM C234 (1991). Standard test Method for comparing concrete based on bond developed with reinforcing steel. West Conshohocken, PA: American Society for Testing and Materials.

ASTM C31 (2011). Standard Practice for Making and Curing Concrete Test Specimens in the Field. West Conshohocken, PA: American Society for Testing and Materials.

ASTM D790 (2014). Standard Test Method for Flexural Properties of Unreinforced and reinforced Plastics and Electrical Insulating Materials. West Conshohocken, PA: 300 American Society for Testing and Materials.

Bertolini, L.; B. Elsener; P. Pedeferri and R. P Polder. (2004). Corrosion of Steel in Concrete, WILEY-VCH Verlag $\mathrm{GmbH} \& \mathrm{Co} \mathrm{KGaA}$, Weinheim.

BS 1881 (2011). "Testing of Concrete", British Standards Institution, London.

BS EN 12390-3: (2009). Testing Hardened Concrete. Compressive Strength of Test Specimens.

Standard Institution, London.

BS EN 1542. (1999). Products and systems for the protection and repair of concrete structures. Test methods - Measurement of bond strength by pull-off, British Standard Institution, London.

BS 8550 (2010). Guide for the auditing of water quality sampling. British Standard Institution, London.

BS 5400-4 (1990). The design of concrete highway bridges and structures. British Standard Institution, London.

BS 8110-1(1997). Structural use of Concrete. British Standard Institution, London.

Cabrera, J. G. and Ghoddoussi, P. (1992). The effect of reinforcement corrosion on the strength of the steel/concrete bond. Proceedings of International Conference on Bond in Concrete (ICBC 1992), Riga, Latvia, 1-12.

Criado, M.; D.M. Bastidas; S. Fajardo; A. FernandezJim and J.M. Bastidas. (2011). Corrosion the behaviour of a new low-nickel. Cement and Concrete Composites, 33 (6): 644-652.

Demis S, Pilakoutas K, Apostolopoulos, C.A. (2010). Effect of corrosion on bond strength of steel and non-metallic reinforcement. Materials and Corrosion. 61: 328-331.

Falade F., Oyekan G.L, (2006). Bond strength of reinforced laterized concrete beams. $31^{\text {st }}$ conference on Our World in Concrete and Structures, Singapore; $16^{\text {th }}-17^{\text {th }}$ August. 
Gaidis J.M. (2004). Chemistry of corrosion Inhibitors. Cement and concrete composite. 26: 181-189.

Gurten, A.A; M. Erbil and K. Kayakirilmaz. (2005). Effect of " polyvinylpyrrolidone on the corrosion resistance of steel," Cement and Concrete Composites, 27 (78): 802-808.

Igba, U.T.; J.O. Akinyele; F.M. Alayaki and S.I Kuye. (2019). Causes of failure in concrete element buried in lagoon water. Engineering Failure Analysis. 102: 425-432.

Isgor O.B, Razaqpur A.G. (2006). Modelling steel corrosion in concrete structures. Materials and Structures. 39: 291-302.

Jamil, H.E.; A. Shriri; R. Boulif; M.F. Montemor and M.G.S Ferreira. (2005). Corrosion behaviour of reinforcing steel exposed to an amino alcohol-based corrosion inhibitor. Cement and Concrete Composites, 27 (6): 671-678.

Kumar V. (1998). Protection of Steel Reinforcement for Concrete: A Review. Corrosion Reviews 16 (4): 317-358.

Langford P., Broomfield J. (1987). Monitoring the corrosion of reinforcing steel. Construction Repair. 1(2): 3236.

Li Z., Leung C., Xi Y. (2009). Structural renovation in concrete. Taylor \& Francis, NY, USA.

Liu Y., Weyers R.E. (1998). Modelling the time-tocorrosion cracking in chloride contaminated reinforced concrete structures. ACI Materials Journal. 95(6): 675-681.

Maslehuddin, M; I. Rasheeduzzafar and A.I. AlMana. (1992). Strength and corrosion resistance of superplasticizer concretes. Journal of Materials in Civil Engineering. 4(1): 108-113.

Mehta P.K, and Monteiro P.J.M. (2006). Concrete Microstructure, Properties and Materials. Mcgraw Hill, London.

Morris W and Vazquez M. (2002). A migrating corrosion inhibitor 'evaluated in concrete containing various contents of admixed chlorides," Cement and Concrete Research, 32 (2): 259- 267.

Mullick D.A.K. (2004). Corrosion of reinforcement in concrete-an interactive durability problem. The Indian Concrete Journal. 74: 168-175

Neville AM. (2012). Properties of Concrete, Fifth Ed., Pearson Educational Limited, Harlow. U.K

Paul S.C., Van Zijl G.P.A.G. (2017). Corrosion deterioration of steel in cracked SHCC. International Journal of Concrete Structures and Materials. 11(3): 557-572.

Sanjeev, K.V; S.B. Sudhir and A. Saleem. (2014). Monitoring Corrosion of Steel Bars in Reinforced Concrete Structures. The Scientific World Journal. Available online at: http://dx.doi.org/10.1155/2014/957904. Accessed on September 21, 2020.

Sideris K.K and Savva A.E. (2005). Durability of mixtures containing calcium nitrite based corrosion inhibitor. Cement and Concrete Composites, 27 (2): 277-287.

Suvash C.P, and Adewumi J.B. (2018). A Review on Reinforcement Corrosion Mechanism and Measurement Methods in Concrete. Civil Engineering Research Journal. 5(3): 80-90.

Torres S.M.; C.A. Kirk; C.J. Lynsdale; R.N. Swamy; and J.H. Sharp. (2004). Thaumasiteettringite solid solutions in degraded mortars. Cement Concrete Research. 34 (8): 1297-1305.

Van Zijl G.P.A.G and Paul S.C. (2018). A novel link of the time scale in accelerated chloride-induced corrosion test in reinforced SHC. Construction and Building Materials. 167: 15-19.

Xu H.; Z. Chen; B. Xu and D. Ma. (2012). Impact of low calcium fly ash on steel corrosion rate and concrete-steel interface. The Open Civil Engineering Journal, 6 (1): 1-7. 